\title{
Personal characteristics associated with injecting drug use among Latinas in the United States of America ${ }^{1}$
}

\author{
Jorge Delva, ${ }^{2}$ Carolyn D. M. Furr, ${ }^{2}$ and James C. Anthony ${ }^{2}$
}

ABSTRACT This study examines nonmedical injecting drug use (IDU) among Latinas aged 12 years and older in a nationally representative sample of U.S. households. Data from the 1990-1995 National Household Surveys on Drug Abuse disclosed 154 Latinas with self-reported histories of IDU out of 18335 Latinas who responded. Hypotheses about correlates of IDU were tested by using the conditional form of multiple logistic regression to compare the characteristics of these IDUs with those of 602 noninjecting Latinas matched on neighborhood of residence. In the USA, an estimated 1\% of Latinas age 12 years and older have injected drugs for nonmedical purposes on at least one occasion. IDU was 4.6 to 6.5 times greater for adult Latinas (18-44 years old) when compared to Latinas aged either 12 through 17 years $(\mathrm{P}<0.05)$ or older than 44 years. IDU was an estimated 7.1 times greater for Latinas who reported marijuana use and 5.4 times greater for Latinas who reported inhalant use when compared to Latinas not using these drugs $(\mathrm{P}<0.01)$. In light of recent studies indicating that IDU is a serious public health problem for Latinas in the United States, the observed associations represent first steps in an effort to understand the Latina subgroups most affected by IDU and the underlying risk factors or causes of this behavior.

Recent data indicate that injecting drug use (IDU) is the second most important risk factor for HIV infection among Hispanic females living in the United States (hereinafter, Latinas), and the primary factor among some Latina subgroups (e.g., Puerto Ricans) (1-4). In 1997, the National Institute on Drug Abuse Hispanic Initiative work

\footnotetext{
1 This project was supported by training grant T32DA07292 from the National Institute on Drug Abuse and research grant award DA10502.

2 Johns Hopkins University School of Hygiene and Public Health, Department of Mental Hygiene. All correspondence should be addressed to James C. Anthony at the following mailing address: Johns Hopkins University, School of Hygiene and Public Health, 624 N. Broadway, 8th Floor, Baltimore, Maryland 21205. Fax: 410-955-9088. E-mail: janthony@jhu.edum
}

group expressed concern that alarmingly increased rates of IDU were being observed in Hispanic communities, particularly among Latinas. To better understand this problem, we examined the association between Latina IDU and selected demographic characteristics (age, marital status, education, work status) and lifetime use of alcohol, marijuana, and inhalant drugs. The latter have all been cited as possible risk factors for subsequent development of IDU (5).

We utilized data from the public files of the 1990-1995 National Household Surveys on Drug Abuse (NHSDA). The NHSDA employs a multistage area probability sampling design of civilians aged 12 years and older living in the U.S. (6). It oversamples Hispanic Americans to increase the precision of estimates for this population subgroup.

In this study, injecting drug use refers to any self-reported past or recent history of injecting of heroin, stimulants, or cocaine for nonmedical reasons. The Latina category is based on respondents' self-reports of their race/ethnic backgrounds. Respondents were grouped into strata or risk sets defined by the block groups and area segments where they were living when sampled, henceforth referred to as neighborhoods. Post-stratified risk sets were created to match Latinas reporting IDU with Latinas reporting no IDU in each neighborhood. This 
matching strategy was chosen in response to the wide variety of social and geographic backgrounds among Hispanic people (7). The purpose is to minimize confounding due to differences in community-level characteristics with a suspected impact on IDU prevalence (e.g., norms and attitudes toward drug use generally and toward IDU in particular, drug availability, social disadvantage shared across the neighborhood).

The estimate of lifetime prevalence of IDU among Latinas in the U.S. and its confidence interval were derived by a Taylor series approximation using the statistical package STATA, version 5.0 (8). This method allows adjustment for variation in sampling weights, post-stratification adjustments to population characteristics, and design effects found in the NHSDA. We used the conditional form of multiple logistic regression to analyze the matched data. This model takes into consideration the post-stratification of respondents into risk sets (9).

The estimated lifetime prevalence of IDU among Latinas in the U.S. is approximately $1 \%(\mathrm{SE}=0.0009)$. Table 1 compares the 154 Latinas from 143 neighborhoods who reported IDU and
602 matched Latinas from the same neighborhoods who did not report IDU. IDU was concentrated among Latinas age 18-44, whose odds were estimated to be 4.6 to 6.5 times higher than that of Latinas aged $12-17(P<0.05)$. The occurrence of IDU among Latinas older than 44 did not differ from that among those aged 12-17. In separate calculations (not shown), injecting drug use was found to be $40 \%$ more common among Latinas aged 35-44 than among Latinas aged 18-24 or 25-34, and $260 \%$ more common among Latinas ages 35-44 than among Latinas aged 45 years and older.

TABLE 1. Sociodemographic characteristics associated with Latina injecting drug use (IDU) ${ }^{\mathrm{a}}$

\begin{tabular}{|c|c|c|c|c|c|c|}
\hline \multirow[b]{2}{*}{ Characteristic } & \multicolumn{2}{|c|}{$\begin{array}{l}\text { Latinas reporting IDU } \\
\qquad(n=154)\end{array}$} & \multicolumn{2}{|c|}{$\begin{array}{l}\text { Latinas reporting no IDU } \\
\qquad(n=602)\end{array}$} & \multirow{2}{*}{$\begin{array}{l}\text { Estimated OR } \\
(95 \% \mathrm{Cl})\end{array}$} & \multirow[b]{2}{*}{$P$ value } \\
\hline & No. & $\%$ & No. & $\%$ & & \\
\hline $12-17$ & 20 & 13.0 & 145 & 24.1 & 1.0 & \\
\hline $18-24$ & 33 & 21.4 & 126 & 20.9 & $4.6(1.2-17.7)$ & 0.02 \\
\hline $25-34$ & 67 & 43.5 & 127 & 31.7 & $4.7(1.2-17.8)$ & 0.02 \\
\hline \multicolumn{7}{|l|}{ Marital status } \\
\hline Married & 50 & 32.5 & 210 & 34.9 & 1.0 & \\
\hline Widowed & 1 & 0.6 & 27 & 4.5 & $0.5(0.04-5.1)$ & 0.50 \\
\hline Divorced & 34 & 22.1 & 77 & 12.8 & $1.5(0.7-3.4)$ & 0.30 \\
\hline Never married & 35 & 39.0 & 213 & 35.4 & $1.1(0.6-2.2)$ & 0.70 \\
\hline Missing & 9 & 5.8 & 75 & 12.5 & - & \\
\hline \multicolumn{7}{|l|}{ Work status ${ }^{b}$} \\
\hline Employed & 61 & 39.6 & 225 & 37.4 & 1.0 & \\
\hline Unemployed & 22 & 14.3 & 37 & 6.1 & $1.5(0.6-3.7)$ & 0.40 \\
\hline Other & 71 & 46.1 & 340 & 56.5 & $1.4(0.7-2.7)$ & 0.40 \\
\hline \multicolumn{7}{|l|}{ History of alcohol use } \\
\hline Yes & 144 & 93.5 & 388 & 64.5 & $3.0(0.9-9.3)$ & 0.06 \\
\hline No & 10 & 6.5 & 214 & 35.5 & 1.0 & \\
\hline \multicolumn{7}{|c|}{ History of marijuana use } \\
\hline Yes & 120 & 77.9 & 133 & 22.1 & $7.1(3.7-13.8)$ & $<0.001$ \\
\hline No & 34 & 22.1 & 469 & 77.9 & 1.0 & \\
\hline \multicolumn{7}{|c|}{ History of inhalant drug use } \\
\hline
\end{tabular}

a Data source: Multiple regression analysis of data from National Household Surveys on Drug Abuse, 1990-1995.

b The employment category refers to people working full-time ( 35 or more hours per week) or part-time (less than 35 hours per week). The "other" category refers to people who responded that they were full-time homemakers, in school, retired, unable to work because of disability, or otherwise not in the labor force. 
Latinas with past or current histories of using marijuana or inhalant drugs were more likely to have reported IDU. Specifically, the odds were an estimated 7.1 times greater for Latinas who reported marijuana use (95\%CI: 3.7 to 13.8 ) and 5.4 times greater for Latinas who reported inhalant drug use (95\%CI: 2.4 to 12.3 ) compared to Latinas who reported never using these agents. IDU among Latinas in this sample was not associated with marital status, employment status, or educational attainment.

A supplementary analysis showed that, compared to neighborhoods in which no Latina reported IDU, those in which at least one Latina did report IDU tended to (1) include a larger share of adults, (2) have fewer Latinas with a high school diploma, and (3) be in the western United States (Table 2). Neighborhoods with injecting Latinas were somewhat more likely to be located in large metropolitan areas, rather than in small metropolitan or nonmetropolitan areas.

This is the first study to examine IDU among a nationally representative sample of Latinas in the U.S. To our knowledge, it is the first epidemiologic study of Latina injecting drug users and community controls. All of the findings are consistent with those from previous studies of IDUs in the general population $(5,10)$.

The study has several limitations that affect its interpretation:

- Its cross-sectional design does not permit causal inferences about the association between lifetime use of marijuana and inhalants and injecting drug use. It is likely, though not certain, that injecting drug use follows rather than precedes the use of other drugs. Unfortunately, this issue cannot be addressed with NHSDA data because the age of first IDU is not assessed;

- The use of self-reports might introduce reporting bias, perhaps with underreporting of illicit drug use;

- Individuals not residing in households are not represented in the data (e.g., homeless persons, incarcerated individuals);

TABLE 2. Sociodemographic characteristics of Latinas living in neighborhoods with and without at least 1 Latina reporting injecting drug use (IDU) (unweighted comparison)a

\begin{tabular}{|c|c|c|}
\hline Characteristic & $\begin{array}{l}\text { Latinas in neighborhoods } \\
\text { with at least } 1 \text { Latina } \\
\text { reporting IDU } \\
\text { (756 Latinas; } \\
143 \text { neighborhoods) }\end{array}$ & $\begin{array}{c}\text { Latinas in neighborhoods } \\
\text { with no Latina } \\
\text { reporting IDU } \\
\text { (17 } 733 \text { Latinas; } \\
5418 \text { neighborhoods) }\end{array}$ \\
\hline \multicolumn{3}{|c|}{ Age distribution within neighborhoods } \\
\hline $12-17$ & 21.8 & 24.9 \\
\hline $18-24$ & 21.0 & 20.8 \\
\hline $25-34$ & 34.1 & 31.0 \\
\hline $35-44$ & 12.2 & 11.8 \\
\hline $45+$ & 10.8 & 11.4 \\
\hline \multicolumn{3}{|l|}{$\begin{array}{l}\text { Marital status distribution } \\
\text { within neighborhoods }\end{array}$} \\
\hline Married & 34.4 & 36.9 \\
\hline Widowed & 3.7 & 3.2 \\
\hline Divorced & 4.7 & 12.3 \\
\hline Never married & 36.1 & 34.9 \\
\hline Missing & 11.1 & 12.7 \\
\hline \multicolumn{3}{|c|}{$\begin{array}{l}\text { High school graduate distribution } \\
\text { within neighborhoods }\end{array}$} \\
\hline Yes & 36.1 & 42.6 \\
\hline No & 63.9 & 57.4 \\
\hline \multicolumn{3}{|c|}{$\begin{array}{l}\text { Work status distribution within } \\
\text { neighborhoods }\end{array}$} \\
\hline Employed & 40.3 & 41.6 \\
\hline Unemployed & 7.8 & 6.7 \\
\hline Other & 51.9 & 51.7 \\
\hline \multicolumn{3}{|c|}{$\begin{array}{l}\text { Population density of neighborhood } \\
\text { location }\end{array}$} \\
\hline Large metropolitan & 79.8 & 74.9 \\
\hline Small metropolitan & 16.3 & 19.9 \\
\hline Nonmetropolitan & 4.0 & 5.2 \\
\hline \multicolumn{3}{|c|}{ Census region of neighborhood } \\
\hline Northeast & 13.8 & 15.5 \\
\hline North Central & 4.1 & 7.9 \\
\hline South & 29.9 & 36.3 \\
\hline West & 52.2 & 40.3 \\
\hline
\end{tabular}

a Data source: National Household Surveys on Drug Abuse, 1990-1995.

- The category "Latinas" represents an ill-defined grouping of women of widely different geographical and cultural backgrounds (e.g., Puerto Ricans, Cubans, Mexicans). The small sample sizes of the Hispanic American subgroups in the NHSDA forced us to perform aggregate analyses for the combined Latina category. Our sampling design attempted to control confounding due to this diversity by matching IDUs with controls from the same neighborhoods.
These findings provide new details on the associations between IDU and age, marijuana use, and inhalant use among the Latina population of the U.S. However, the mechanisms that explain transitions into IDU remain unknown. We speculate that two common links are a prior drug history and exposure to an opportunity to inject drugs. These hypotheses accord with prior research that showed that drug use occurs in progressive stages, with level of use and consequences inversely related to the age of initiation 
(11-15). However, prior investigations have paid scant attention to identifying precursors of IDU in Hispanic communities and have generally focused on the behavior of male IDUs.

The estimated magnitude of the associations of IDU with marijuana and inhalant drugs is strong enough to warrant a special focus on Latinas who use these agents as part of IDU outreach, prevention, and early intervention services. A surprising aspect of our results is an apparent departure from Kandel's stage theory, in that the link between marijuana use and IDU is independent of the link between inhalant drug use and IDU. The independent association with inhalant drug use is noteworthy because inhalant drugs often are ig- nored in the planning and consideration of IDU prevention programs.

Finally, there is a recent trend toward more marijuana smoking among Latinas aged 12-17 years. The NHSDA marijuana prevalence estimates for adolescent Latinas were $9.8 \%$ in 1992 , $11.5 \%$ in $1993,12.9 \%$ in $1994,14.2 \%$ in 1995 , and $16.6 \%$ in 1996 (6). These statistics suggest that the rate of IDU may also rise. The trend warrants close scrutiny.

In view of trends such as these, it is important to identify the ages and situations in which Latinas begin to have opportunities to initiate IDU, the determinants of these opportunities, and why some Latinas act on them while others do not. Interestingly, the results of our secondary analyses hint that Latina IDUs might be more concentrated in large metropolitan areas, and these are the areas where Latinas might have a greater opportunity to inject drugs. This type of variation in the occurrence of IDU can be incorporated in planning IDU prevention initiatives, just as these initiatives now are guided by attention to differences in acculturation, socioeconomic status, religiosity, familialism, extended kinship networks, and folk beliefs among the various Latina groups $(7,16-18)$. Carefully controlled, epidemiologically based prevention trials can examine the mechanisms involved in making the transition to IDU in the course of trying to forestall such transitions.

\section{REFERENCES}

1. Centers for Disease Control and Prevention. AIDS associated with injecting-drug use in the U.S., 1995. JAMA 1996;275:1628-1629.

2. Centers for Disease Control and Prevention. 1996 HIV/AIDS surveillance report. [Internet site]. Available: http://cdcnac.org:72/0/ 4midyear96/intro96.txt. Accessed 17 November 1997

3. Robles RR, Colón HM, Sahai H, Matos TD, Marrero CA, Reyes JC. Behavioral risk factors and human immunodeficiency virus (HIV) prevalence among intravenous drug injectors in San Juan. Am I Epidemiol 1992;135:531-540.

4. Díaz T, Buehler JW, Castro KG, Ward JW. AIDS trends among Hispanics in the United States. Am J Public Health 1993;83:504-509.

5. Schütz CG, Chilcoat HD, Anthony JC. The association between sniffing inhalants and injecting drugs. Compr Psychiatry 1994;35: 99-105.

6. Substance Abuse and Mental Health Services Administration. National household survey on drug abuse: Main findings 1992, 1993, 1994, 1995, 1996. DHHS Publication Nos. (SMA) 943012, (SMA) 95-3020, (SMA) 96-3085, (SMA) 97-3127, (SMA) 98-3200. Rockville, MD: U.S. Department of Health and Human Services, 1994, 1995, 1996, 1997, 1998.
7. De La Rosa MR, Khalsa JH, Rouse BA. Hispanics and illicit drug use: A review of recent findings. Int J Addictions 1990;25:665-691.

8. Stata Corporation. STATA 5.0 Statistics/Data Analysis. College Station, Texas: STATA; 1996

9. Statistics and Epidemiologic Research Corporation and Cytel Software Corporation. EGRET reference manual (First Draft). Seattle, Washington: SERC and CSC; 1993.

10. Neumark YD, Anthony JC. Childhood misbehavior and the risk of injecting drug use. Drug Alcohol Depend 1997;48:193-197.

11. Kandel DB. Stages in adolescent involvement in drug use. Science 1975;190:912-914.

12. Chen K, Kandel DB. The natural history of drug use from adolescence to the mid-thirties in a general population sample. Am J Public Health 1995;85:41-47.

13. Delva J, Van Etten M, González G, Cedeño M, Penna M, Caris L, et al. First opportunities to try drugs and the transition to first drug use: Evidence from a national school survey in Panama. Substance Use Misuse. In press.

14. Grant BF, Dawson DA. Age of drinking onset predicts future alcohol abuse and dependence. J Substance Abuse Treat 1997;9:103-110.

15. Van Etten ML, Neumark YD, Anthony JC. Initial opportunity to use marijuana and the transition to first use: United States, 1979 to 1994. Drug Alcohol Depend 1997;49:1-7.

16. Félix-Ortiz M, Fernández A, Newcomb MD. The role of intergenerational discrepancy of cultural orientation in drug use among Latina adolescents. Substance Use Misuse 1998;33: 967-994.

17. Katims DS, Zapata JT. Gender differences in substance use among Mexican American school-age children. J School Health 1993;63: 397-401.

18. Singer M, Jia Z, Schensul JJ, Weeks M, Page JB. AIDS and the IV drug user: The local context in prevention efforts. Med Anthropol 1992;14:285-306.

Manuscript received on 24 November 1997. Revised version accepted for publication on 7 July 1998. 
RESUMEN En el presente estudio se examina el uso de drogas inyectables (UDI) entre latinas de 12 años de edad y mayores en una muestra nacional representativa de hogares estadounidenses. Datos obtenidos de las Encuestas Nacionales Domiciliarias realizadas

Características personales de las latinas usuarias de drogas inyectables en los Estados Unidos de América de 1990 a 1995 revelaron que 154 de un total de 18335 latinas encuestadas habían referido tener antecedentes de UDI. Se pusieron a prueba diversas hipótesis sobre las variables relacionadas con el UDI mediante una regresión logística múltiple de tipo condicionado destinada a comparar las características de estas usuarias con las de 602 latinas que no usaban drogas inyectables y que se parearon con las usuarias por lugar de residencia. Se estima que en los Estados Unidos de América 1\% de las latinas de 12 años o más han usado drogas inyectables para fines no médicos por lo menos en una ocasión. El UDI fue de 4,6 a 6,5 veces más frecuente entre latinas adultas (de 18 a 44 años) al comparar a este grupo con el de latinas de 12 a 17 años $(P<0,05)$ o de más de 44. El uso estimado de drogas inyectables fue 7,1 veces más frecuente entre las latinas que dijeron haber fumado marijuana y 5,4 más frecuente entre las latinas que dijeron haber inhalado sustancias en comparación con las que no usaban estas drogas $(P<0,01)$. A la luz de los estudios recientes que señalan que el UDI es un serio problema de salud pública para la población de latinas en los Estados Unidos, las asociaciones observadas representan los primeros pasos de una tentativa por entender cuáles son los subgrupos de latinas más afectados por el UDI y por los factores de riesgo o causas subyacentes que llevan a esta conducta.

\section{ERRÁTUM}

Galindo, et al., "La eliminación del sarampión en Cuba"

(Rev Panam Salud Publica/Pan Am J Public Health 1998;4(3): 171-177)

Se llama la atención de los lectores a un error de traducción que aparece en la figura 1, p. 173. La primera, de izquierda a derecha, de las tres flechas que están dentro de la figura debe decir "Vacunación de puesta al día" en vez de "Vacunación de cobertura básica". Lamentamos el error, que ha ocurrido por entera responsabilidad de nuestra redacción. 